\title{
Childhood encephalopathy due to thiamine pyrophosphokinase deficiency
}

INSERM

\section{Source}

INSERM. (1999). Orphanet: an online rare disease and orphan drug data base. Childhood encephalopathy due to thiamine pyrophosphokinase deficiency. ORPHA:293955

Childhood encephalopathy due to thiamine pyrophosphokinase deficiency is a rare inborn error of metabolism disorder characterized by early-onset, acute, encephalopathic episodes (frequently triggered by viral infections), associated with lactic acidosis and alpha-ketog lutaric aciduria, which typically manifest with variable degrees of ataxia, generalized developmental reg ression (which deteriorates with each episode) and dystonia. Other manifestations include spasticity, seizures, truncal hypotonia, limb hypertonia, brisk tendon reflexes and reversible coma. 